\title{
The Relationship of Outdoor Management Development and Organizational Mission
}

\author{
Rita Ambarwati \\ Magister Manajemen \\ Universitas Muhammadiyah Sidoarjo \\ Sidoarjo, Indonesia \\ ritaambarwati@umsida.ac.id
}

\author{
Gogor Arif Handiwibowo \\ Dept. of Management of Technology \\ Institut Teknologi Sepuluh Nopember \\ Surabaya, Indonesia
}

\begin{abstract}
The method of Outdoor Management Development (OMD) is a trend that is mostly done by an organization for self-development of members and form a pattern of relationships among its members as the output of activities. OMDs own activities aimed at new students have several objectives to be achieved.On the other hand, Post-Graduate of University as a form of organization also has the vision of the organization as a qualitative reference scale to be achieved and described in more detail within the mission of the organization. In this research will be analyzed the relationship between OMD objectives scientificall and internally with Post-Graduate of University education mission statement. The hypothesis was analyzed using Generalized Structured Component Analysis (GSCA) to determine the relationship.The results of this study indicate that OMD scientific objectives directly have a significant effect on the mission of postgraduate programs. The ultimate goal of OMD science directly affects the OMD's internal objectives. Furthermore, OMD's scientific objectives directly have a significant effect on the mission of the graduate program. The practical implications of this research, for graduate program management, need to improve the achievement of OMD's scientific and internal objectives in an effort to improve the achievement of the mission of the graduate program. This research develops organizational behavior theory by using the achievement of OMD objectives both scientifically and internally as one element that can improve the mission of the post-graduateprogram.
\end{abstract}

Keywords-Outdoor Management Development (OMD) objective; Post-Graduate of University education mission statement; Generalized Structured Component Analysis (GSCA)

\section{INTRODUCTION}

Understanding the characteristics of an organization becomes very important in the view of resource-based theory (RBT). Through the organization's internal understanding and organizational characteristics, an organization is able to find it's competitive advantage so that it can compete with other organizations [1].

Understanding the characteristics of the organization cannot be separated from the organizational behavior that is in it. Organizations must be effective in order to be competitive.
There are four main components for the organization to be effective. The main components of the effective organization are the resources they possess, the composition equilibrium, the work design/role and the process variables they contain [2].

In the organizational process, resources should be given treatment to be as expected by the organization. Likewise, human resources must also be given special treatment in order to have criteria appropriate to the organization wants. One form of special treatment for human resources is training provided [2].

Around the 90s, training with Outdoor Management Development (OMD) method became a very popular method for improving the quality of human resources within an organization [3]. This method until now is still widely used by organizations either in the form of profit organizations to nonprofit organizations. Several studies have reported and provided evidence of the impact of team building training in teamwork that is usually one of the lessons learned in the OMD method in some organizational models [4,5,6]. Even organizations operating in educational areas are also implementing OMD methods to improve the quality of their human resources. Some researchers report the effectiveness of OMD methods for organizations in the field of education $[7,8,9]$.

As an organization, the Postgraduate also has the vision and mission of the organization as a reference all the activities that are in it. This vision and mission which for several periods will be evaluated related to its achievement. By evaluating the achievement of vision and mission of the organization can be seen how the achievement of Postgraduate in reaching its strategic competitiveness [10].

This paper is based on research in strategic areas of management and organizational behavior. in this study will be analyzed the correlation between the objectives of an activity related to organizational against the organizational mission that has been set previously. It is necessary to see the implementation process of the strategic formulation established by an organization [1].

\section{OUTDOOR MANAGEMENT DEVELOPMENT (OMD)}

Outdoor Management Development (OMD) is an outdoor training activity or outdoors. OMD activities are implemented with life simulation activities that are applied in 
the form of educative, creative, attractive, and recreational games. Through OMD training it is expected to transform old individuals into new, motivated, courageous, confident, creative-thinking, shared, responsibility, cooperative and trusting individuals [8].

OMD is one of experimental learning method based learning. The learning media is using challenging games given to participants with certain rules and goals. Every game in the OMD activities is meaningful, philosophical, and loaded with useful symbolic messages and helps in the process of building character toward success in life, both individual success and team success. The OMD method is the most effective method of accommodating/demanding requirements for training outcomes. This method is effective in building an understanding of a concept at the personal and team level and able to build the behavior of individual characters [11].

The postgraduate as an organization has the purpose of its OMD activity. In this paper, the purpose of OMD activity will be divided into 2 categories. OMD objectives are scientifically (based on a scientific literature) and the purpose of internal management postgraduate. The description of the purpose of OMD activity is scientifical as follows [12]:

1. Train effective communication

2. Train Team building

3. Train Problem Solving

4. Training Self-confidence

5. Leadership Training

6. Coaching Cooperation (Synergy)

7. Coaching Games entertain and fun (fun games)

8. Train Concentration / focus

9. Train Honesty / sportsmanship (fairness)

While the purpose of internal postgraduate obtained from the interview process with the management of postgraduate and produced some things as follows:

1. Awaken the sense of owning the alma mater

2. Awaken pride in the alma mater

3. Enhance the egalitarian sense of fellow students

4. Improving the ability of public speaking

5. Increase the ability of scientific debate

\section{Vision and Mission Statement}

The vision and mission statement are one of the product of the strategy formulation process in strategy management. Vision is the future view of an organization. Vision is a basic factor that reflects the current situation comprehensively, reinforces organizational goals and implies an organizational component and the realization of the organization's strategic management. Vision is the choice and lifestyle of the organization [13]. A good vision statement should be able to clearly explain in which direction an organization will move [14].

A mission statement can be defined as a continuous statement of goals that reveal the organization's product or service to the market, its customers and its philosophy[15]. Mission statements are addressed to answer some fundamental questions in organizations such as why this organization exists, what is the purpose of this organization, where the direction of this organization is, what the organization wants to achieve and so forth $[16,17]$.

An effective mission statement is to define fundamentally different or unique goals for defining a company's business that is separate from another company and identify the scope of its business, product and market operations. Furthermore, mission statements specify the fundamental reasons why organizations exist [18].

In this case study the organization Mission Postgraduate Field of Education will be analyzed correlation that is:

1. Conducting graduate educational activities and developing a future-oriented curriculum with highlevel and up-to-date competencies to respond and adapt to change

2. Producing qualified graduates in the field of Technology Management

3. Produce graduates high commitment in the field of Technology Management

4. Develop an innovative teaching and learning process by providing educational facilities / educational infrastructure and a conducive academic atmosphere

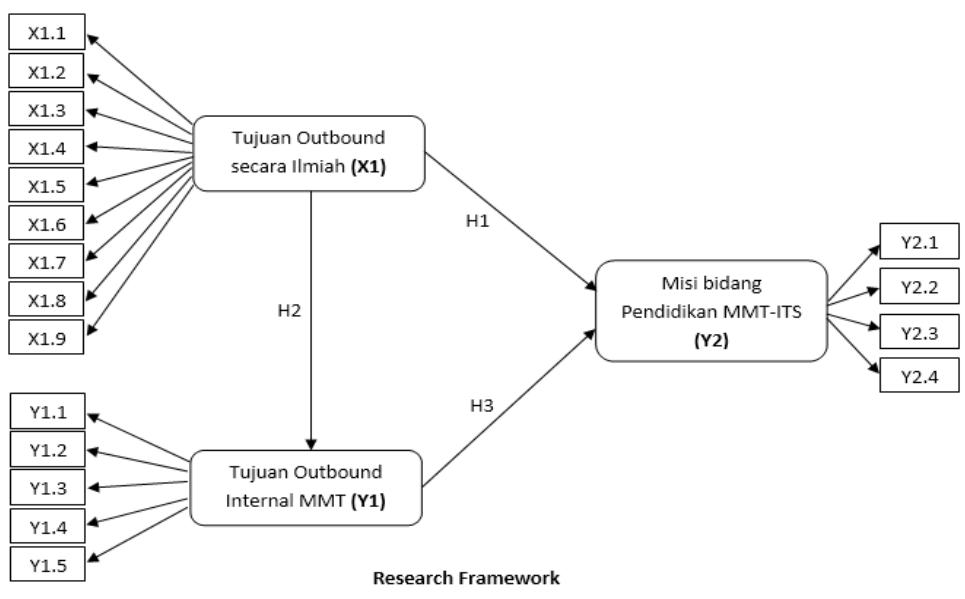

\section{METHODOLOGY}

Based on existing problems then this research is causality. This study aims to examine and explain the causal relationship between the scientific objectives and the internal objectives of outbound activities towards the graduate missions. Information obtained about the clarity of the relationship between variables built on a model of the equation based on the relevant concept so that this research is classified as explanatory research.

Empirical data were obtained through random survey to the post-graduate students who have attended the outbound training program and have attended the lecturing program in post graduate so it is assumed to have known and understood the mission of education in post-graduate. The survey was conducted in the period of March - April 2017 to students of semesters 2 and 3 . Out of a total of 160 questionnaires distributed, 102 questionnaires were returned. Thus approximately $63.8 \%$ of the total questionnaires are distributed into data and can be processed. Of the 102 returned questionnaires, 63 were questionnaires from $2^{\text {nd }}$ semester students and 39 questionnaires were from students of the $3^{\text {rd }}$ semester.

The location of this research is on postgraduate campus in Surabaya area. The reason for choosing research location in Surabaya as research location is Surabaya Region as one of the second largest regions in Indonesia where many universities open graduate programs for business expansion; industrial development and per capita income in the Surabaya 
region increased where the market share to absorb postgraduate graduate employment in all industries remains open. This research was conducted within two months ie August until September 2017.

The population in this study is all postgraduate students who have participated in outbound activities held by the university, and have attended lectures at least 2 semesters. Characteristics of the population studied were infinite where the size of the population studied was unknown. The sample size in this study was 102 postgraduate students from 160 questionnaires distributed and taken from all postgraduate campuses in Surabaya area. Sampling and interviews were conducted by visiting respondents directly to every graduate campus in Surabaya.

Data collection method of this research surveys, conducted by giving questionnaires containing questions to the students according to population criteria. Spreading of questionnaires done by directly encounter prospective respondents on the campus of the postgraduate area of Surabaya during the hours of college $(08.00-21.00 \mathrm{WIB})$ ie at the time before the prospective respondents follow the lectures; In-depth interviews, this technique is used to support and uncover the facts behind quantitative analysis and provide a substantial explanation of the study's study. Measurement data in this study using a Likert scale to measure attitudes, opinions, and perceptions of respondents to the object.

\section{DATA AND RESULTS ANALYSIS}

The analysis used to answer the hypothesis in this study using a model of structural equations based on component (Generalized Structural Component Analysis) with Visual GSCA1.0 software. The reasons behind the selection of GSCA (Generalized Structural Component Analysis) model in this research are the model formed on the conceptual framework of this research. There is a causal relationship between the objectives of scientific outbound and internally affect the mission of postgraduate education. The research variables analyzed by indicator model are reflexive in order to use GSCA analysis. In addition, GSCA does not require the assumption of normal distribution.

TABLE 1 CONSTRUCT AND INDICATOR ANALYSIS

\begin{tabular}{|c|c|c|c|c|c|c|}
\hline \multirow[b]{2}{*}{ CONTRUCT } & \multirow{2}{*}{$\begin{array}{c}\text { INDICA } \\
\text { TOR }\end{array}$} & \multirow[t]{2}{*}{ MEAN } & \multicolumn{2}{|c|}{ LOADING } & \multirow{2}{*}{$\begin{array}{l}\text { Akar } \\
\text { AVE }\end{array}$} & \multirow{2}{*}{$\begin{array}{c}\text { ALP } \\
\text { HA }\end{array}$} \\
\hline & & & $\begin{array}{r}\text { ESTI } \\
\text { MATE } \\
\end{array}$ & CR & & \\
\hline \multirow[t]{6}{*}{$\begin{array}{l}\text { Scientific } \\
\text { (X1) }\end{array}$} & $\begin{array}{l}\text { Effectiv } \\
\mathrm{e} \\
\text { Commu } \\
\text { nication } \\
(\mathrm{X} 1.1)\end{array}$ & 3.48 & 0.843 & $18.95^{*}$ & 0.592 & 0.909 \\
\hline & $\begin{array}{l}\text { Team } \\
\text { Building } \\
\text { (X1.2) }\end{array}$ & 3.73 & 0.814 & $16.23^{*}$ & & \\
\hline & $\begin{array}{l}\text { Problem } \\
\text { Solving } \\
\text { (X1.3) }\end{array}$ & 3.78 & 0.727 & $6.16^{*}$ & & \\
\hline & $\begin{array}{l}\text { Self- } \\
\text { confiden } \\
\text { ce } \\
(\mathrm{X} 1.4)\end{array}$ & 3.83 & 0.761 & $10.81^{*}$ & & \\
\hline & $\begin{array}{l}\text { Leaders } \\
\text { hip } \\
\text { (X1.5) }\end{array}$ & 3.60 & 0.890 & $22.88^{*}$ & & \\
\hline & Synergy & 4.09 & 0.745 & $7.28^{*}$ & & \\
\hline
\end{tabular}

\begin{tabular}{|c|c|c|c|c|c|c|}
\hline \multirow{6}{*}{ CONTRUCT } & \multirow{2}{*}{$\begin{array}{c}\text { INDICA } \\
\text { TOR }\end{array}$} & \multirow[t]{2}{*}{ MEAN } & \multicolumn{2}{|c|}{$\begin{array}{l}\text { LOADING } \\
\end{array}$} & \multirow{2}{*}{$\begin{array}{l}\text { Akar } \\
\text { AVE }\end{array}$} & \multirow{2}{*}{$\begin{array}{c}\text { ALP } \\
\text { HA }\end{array}$} \\
\hline & & & $\begin{array}{c}\text { ESTI } \\
\text { MATE }\end{array}$ & CR & & \\
\hline & (X1.6) & & & & & \\
\hline & $\begin{array}{l}\text { Fun } \\
\text { games } \\
\text { (X1.7) }\end{array}$ & 2.97 & 0.619 & $8.73^{*}$ & & \\
\hline & $\begin{array}{l}\text { Concent } \\
\text { ration } \\
\text { (X1.8) }\end{array}$ & 3.11 & 0.656 & $7.88^{*}$ & & \\
\hline & $\begin{array}{l}\text { Fairness } \\
\text { (X1.9) }\end{array}$ & 3.46 & 0.827 & $23.01^{*}$ & & \\
\hline \multirow[t]{5}{*}{ Internal (Y1) } & $\begin{array}{l}\text { Self- } \\
\text { Belongi } \\
\text { ng } \\
\text { (Y1.1) }\end{array}$ & 3.48 & 0.841 & $28.66^{*}$ & 0.670 & 0.876 \\
\hline & $\begin{array}{l}\text { Campus } \\
\text { Proud } \\
\text { (Y1.1) }\end{array}$ & 3.61 & 0.873 & $30.27^{*}$ & & \\
\hline & $\begin{array}{l}\text { Equality } \\
\text { (Y1.3) }\end{array}$ & 3.92 & 0.834 & $17.33^{*}$ & & \\
\hline & $\begin{array}{l}\text { Public } \\
\text { Speakin } \\
\text { g Skill } \\
\text { (Y1.4) }\end{array}$ & 2.87 & 0.804 & $15.31^{*}$ & & \\
\hline & $\begin{array}{l}\text { Debate } \\
\text { Skills } \\
\text { (Y1.5) }\end{array}$ & 2.72 & 0.733 & $13.15^{*}$ & & \\
\hline \multirow[t]{4}{*}{ Mission (Y2) } & $\begin{array}{l}\text { Curricul } \\
\text { um } \\
\text { (Y2.1) }\end{array}$ & 3.85 & 0.925 & $36.37^{*}$ & 0.820 & 0.924 \\
\hline & $\begin{array}{l}\text { Alumni } \\
\text { Quality } \\
\text { (Y2.2) }\end{array}$ & 3.90 & 0.916 & $26.34^{*}$ & & \\
\hline & $\begin{array}{l}\text { Alumni } \\
\text { Commit } \\
\text { ment } \\
\text { (Y2.3) }\end{array}$ & 3.79 & 0.921 & $44.59^{*}$ & & \\
\hline & $\begin{array}{l}\text { Educati } \\
\text { on } \\
\text { Process } \\
\text { (Y2.4) }\end{array}$ & 3.90 & 0.859 & $14.0^{*}$ & & \\
\hline
\end{tabular}

In this research, the validity test of a construct of research instrument is discriminant validity. The research instrument is said to be valid if the root of AVE is greater than the correlation coefficient of variables/indicators with others. Overall research instrument is valid. Testing instrument reliability research conducted is Alpha analysis, where if alpha $>0.60$ then the research instrument is said to be reliable. Overall research instrument can be said reliable. Overall student respondents have enough response to all indicators of the research variables as indicated by the average assessment of respondents above 3, although there are still low student appraisal ratings only small amount.

Based on the GSCA analysis it appears that the fairness indicator has outer loading $0.827 \mathrm{CR}=23.01$ positive and significant at $\alpha=5 \%$ so it is still the most important indicator to form the outbound scientific objectives variable. Then another indicator shows a significant result so it can be concluded that all indicators are appropriate to measure the outbound scientific objectives variable.

Outer loading test results against the outbound internal objectives variables can be seen that the indicator campus proud is the most important indicator with outer loading 0.873 $\mathrm{CR}=30.27$. Then another indicator shows a significant result 
so it can be concluded that all indicators are suitable for measuring internal outbound objective variable.

Outer loading test results on the mission variables of graduate program can be seen that the indicator of alumni commitment is the most important indicator with outer loading $0.921 \mathrm{CR}=44.59$. Then another indicator shows a significant result so it can be concluded that all indicators are appropriate to measure the mission variables of the postgraduate program.

TABLE 2. RELATIONSHIP VARIABLE

\begin{tabular}{|l|l|l|c|l|l|}
\hline $\begin{array}{l}\text { No } \\
\cdot\end{array}$ & \multicolumn{2}{|l|}{$\begin{array}{l}\text { Relationship } \\
\text { Variable }\end{array}$} & $\begin{array}{l}\text { Path } \\
\text { Coefficien } \\
\mathrm{t}\end{array}$ & $\mathrm{CR}$ & $\begin{array}{l}\text { Descriptio } \\
\mathrm{n}\end{array}$ \\
\hline 1 & $\begin{array}{l}\text { Scientifi } \\
\mathrm{c}\end{array}$ & Internal & 0.807 & $\begin{array}{l}15.15 \\
*\end{array}$ & Significant \\
\hline 2 & $\begin{array}{l}\text { Scientifi } \\
\mathrm{c}\end{array}$ & $\begin{array}{l}\text { Missio } \\
\mathrm{n}\end{array}$ & 0.559 & $4.59^{*}$ & Significant \\
\hline 3 & Internal & $\begin{array}{l}\text { Missio } \\
\mathrm{n}\end{array}$ & 0.328 & $3.01^{*}$ & Significant \\
\hline
\end{tabular}

Description: $*=$ significant at $\alpha 5 \%$

Based on the above table obtained the results of hypothesis testing research as follows:

1. There is a scientific influence on the internal positively and significantly. GSCA results obtained by path coefficient of 0.807 and $\mathrm{CR}=15.15 *$ (significant).

2. There is a scientific influence on mission positively and significantly. GSCA results obtained by path coefficient of 0,559 and $\mathrm{CR}=4,59 *$ (significant).

3. There is an internal influence on mission positively and significantly. GSCA results obtained path coefficient of 0.328 and $\mathrm{CR}=3.01 *$ (significant).

\section{CONCLUSION}

The results showes that the objectives of science directly affect the internal objectives of outbound activities. That the better the achievement of the outbound scientific objectives can improve the achievement of internal outbound objectives. Then the results of this study indicate that the outbound scientific objectives directly affect the mission of the postgraduate program. These findings indicate that the better achievement of internal outbound objectives can improve the achievement of the mission of the post-graduate program. The results of this study also indicate that the internal outbound objective directly affects the mission of the post-graduate program, that the better achievement of outbound internal goals can improve the mission of the post-graduate program.

Based on this research, the accuracy or accuracy of the model analyzed in this study is only 0.634 . This means that the diversity of scientific, internal, and mission variables can be explained by the model of $63 \%$ and the remaining $37 \%$ is explained by other variables. Therefore the researchers can further develop the research model by adding other variables such as organizational culture, commitment, and motivation. In addition, the scope of this research object can be seen more widely not only in post-graduate programs in Surabaya but in other educational programs throughout Indonesia.

\section{REFERENCES}

[1] David, Fred R. (2013), Strategic Management: Concept and Cases, $14^{\text {th }}$ edition, Pearson, Essex.

[2] Robbins, S.P. (2009) Organizational Behavior. 13th Edition. New Jersey: Prentice Hall Pearson Educational International.

[3] Wagner, R.J., Baldwin, T.T., \& Roland, C. (1991). Outdoor Training: Revolution or Fad? Training \& Development Journal, 45(3), 50-57.

[4] Buchori, S. (2011). "Pelatihan Pembentukan Tim untuk Meningkatkan Kohesivitas Tim pada Kopertis V Yogyakarta", Jurnal Psikologi, Vol. 38 No. 1, pp. $40-51$.

[5] Cahyadi, A. (2012), Intervensi Team Building Training untuk Meningkatkan Kepercayaan terhadap Rekan Kerja dan Kualitas Teamwork di PT. S, Master Thesis, Universitas Indonesia.

[6] Setianingtyas, A.F. (2013). Pengaruh Pelatihan Team Building untuk Meningkatkan Kohesivitas Tim Kerja di Inna Garuda Yogyakarta, Naskah Publikasi Master Thesis, Universitas Ahmad Dahlan Yogyakarta

[7] Arifin, Z. (2012). Tren dan Inovasi dalam Pendidikan Manajemen dan Bisnis di Program MM UII Yogyakarta, Proceeding Seminar Nasional APMMI, MK-2-1.

[8] Falah, N. (2014). "Efektifitas Outbound sebagai Metode Pembelajaran (Studi pada Outbound Mahasiswa Jurusan BKI Fakultas Dakwah dan Komunikasi UIN Sunan Kalijaga Yogyakarta)", Jurnal Hisbah, Vol. 11, No. 1. pp. 53-74.

[9] Marimuthu, K.N. \& Mukherjee, S. (2014). Impact of OutBound Training (OBT) on MBA Students in Developing Their Leadership Skill: A Study on South India, International Journal of Innovative Research \& Development, Vol. 3 Issue 12, pp. 384-391.

[10] Handiwibowo, G. A. (2017). Importance Performance Analysis (IPA) Application for External Evaluation of Performance Organisation Mission Statement. Journal of Research and Technology, 3(1), 11-19.

[11] Buchori, S., Ibrahim, M., dan Saman, A. (2016). "Pengaruh Character Education Training melalu OMD untuk Peningkatan Kejujuran dan Integritas", Jurnal Psicologi Pendidikan \& Konseling, Vol. 2 No. 1, pp. $12-19$.

[12] Mulyono \& Asti, B. M. (2008). "Smart games for OMD." Yogyakarta: Diva Press.

[13] Dinçer, Ömer. (2006). Stratejik yönetim ve iletme politikasi, Sekizinci Basim, Istanbul, Alfa Yayim Daitim.

[14] Thompson, A.A. Jr., and Strickland III A.J. (1999). Strategic Management; Concepts and Cases, Irwin Mc Graw Hill, 11th Edition.

[15] Bart, C.K. (1998), "Mission Matters”, The CPA Journal, pp. 5657.

[16] Bart, C.K. (1996a),"The Impact of Mission on Firm Innovativeness", International Journal of Technology Management, Vol. 11. pp. 479-93.

[17] Hitt, M.A., Ireland, R.D. \& Hoskisson, R.E. (2005), Strategic Management: Competitiveness and Globalization (Concept and Cases), $6^{\text {th }}$ edition, South-Western, Ohio.

[18] Staples, W.A. and Black, K.U. (1984), "Defining Your Business Mission: A Strategic Perspective", Journal of Business Strategies, Vol. 1. pp. 33-39.

[19] Sukmono, Rita Ambarwati. 2014. The Role of Multichannel Marketing in Customer Retention and Loyalty: Study in Emerald Bank Customer in Indonesia. Asia-Pasific Management and Business Application. Vol. 2 No. 3. 